\title{
PERILAKU PETANI PENYEMPROT YANG BERHUBUNGAN DENGAN KADAR SERUM CHOLINESTERASE
}

\author{
Behavioral of Spraying Farmer Related to Serum Cholinesterase Levels
}

\author{
Devi Ayu Susilowati ${ }^{1}$, Suhartono² ${ }^{2}$ Bagoes Widjanarko ${ }^{3}$, Mateus Sakundarno Adi', \\ Suratman $^{4}$ \\ 'Program Studi Magister Epidemiologi Universitas Diponegoro, Semarang \\ ${ }^{2}$ Bagian Kesehatan Lingkungan Fakultas Kesehatan Masyarakat Universitas Diponegoro \\ ${ }^{3}$ Bagian Promosi Kesehatan Fakultas Kesehatan Masyarakat Universitas Diponegoro \\ ${ }^{4}$ Bagian Kesehatan Lingkungan Fakultas Ilmu Kesehatan Universitas Jenderal Soedirman \\ (deviayususilowati@gmail.com)
}

\begin{abstract}
ABSTRAK
Petani penyemprot merupakan salah satu populasi berisiko untuk mengalami keracunan pestisida akibat dari aktivitas pertanian yang sangat dekat dengan pestisida. Untuk mengetahui adanya paparan pestisida dan penilaian risiko keracunan pestisida adalah dengan pengukuran kadar serum cholinesterase. Tujuan penelitian ini adalah membuktikan hubungan antara pengetahuan, perilaku merokok ketika menyemprot, dan kelengkapan Alat Pelindung Diri (APD) ketika menyemprot dengan kadar serum cholinesterase pada petani penyemprot. Jenis penelitian ini observasional dengan desain studi cross sectional. Jumlah sampel 88 petani penyemprot di Desa Dukuhlo Kabupaten Brebes. Sampel diambil dengan teknik acak sederhana. Hasil analisis multivariat dengan multipel regresi logistik menunjukkan bahwa faktor yang terbukti berhubungan dengan kadar serum cholinesterase adalah pengetahuan tentang pestisida $\mathrm{p}=0,005(\mathrm{OR}=12,369 ; 95 \% \mathrm{CI}=2,1-71,5)$ dan merokok ketika menyemprot $\mathrm{p}=0,005(\mathrm{OR}=9,641 ; 95 \% \mathrm{CI}=2,0-46,1)$. Petani penyemprot yang memiliki pengetahuan kurang tentang pestisida mempunyai risiko 12,3 kali lebih besar dibandingkan dengan mereka yang memiliki pengetahuan tentang pestisida yang baik dan petani penyemprot yang merokok ketika menyemprot mempunyai risiko 9,6 kali lebih besar dibandingkan dengan mereka yang tidak merokok. Pengetahuan tentang pestisida dan merokok ketika menyemprot terbukti berhubungan dengan kadar serum cholinesterase pada petani penyemprot.
\end{abstract}

Kata kunci: Petani penyemprot, serum cholinesterase, alat pelindung diri (APD)

\section{ABSTRACT}

Spray farmers are is one of the population at risk for pesticide poisoning resulting from very close agricultural activity with pesticides. To determine the presence of pesticide exposure and risk assessment of pesticide poisoning is by measuring serum cholinesterase levels. The purpose of this study was to prove the relationship between knowledge, smoking behavior when spraying, and the completeness of Personal Protective Equipment (PPE) when spraying with serum cholinesterase levels in spraying farmers. This study was observational with cross sectional study design. Total sample of 88 farmer sprayers in Dukuhlo Village of Brebes Regency. The sample is taken by purposive technique. The result of multivariate analysis with multiple logistic regression showed that the factors that proved to be associated with serum cholinesterase were knowledge of pesticide $p=0,005(\mathrm{OR}=$ $12,369 ; 95 \% C I=2,1-71,5)$ and smoking when spraying $p=0,005(O R=9,641 ; 95 \%=C I$ 2.0-46.1). Spray farmers who have less knowledge of pesticides that is 12.3 greater risk than those with good knowledge of pesticides and sprayers who smoke when spray farmer that is 9.6 greater risk than those who do not smoke. Knowledge of pesticides and smoking when spraying has been shown to be associated with serum cholinesterase levels in spray farmers.

Keywords : Sprayer farmer, serum cholinesterase, personal protective equipment (ppe) 


\section{PENDAHULUAN}

Pestisida adalah zat atau campuran zat kimia atau biologi yang digunakan untuk mengontrol hama dan hewan-hewan yang menyebabkan kerusakan atau mengganggu produksi serta mengontrol pertumbuhan tanaman. Efek kesehatan yang ditimbulkan dari paparan pestisida yaitu sebagai zat mutagenik, karsinogenik, pengganggu endokrin, pengganggu sistem reproduksi dan zat neurotoksik. ${ }^{1,2}$ Pestisida bisa masuk ke dalam tubuh melalui digesti, inhalasi dan melalui permukaan kulit yang tidak terlindungi. ${ }^{3}$ Adanya paparan pestisida di dalam tubuh dapat diketahui dengan memeriksa aktivitas enzim cholinesterase. Golongan organofosfat bekerja dengan cara menghambat aktivitas enzim cholinesterase sehingga asetilkholin tidak dapat terhidrolisa dan jumlahnya berlebih yang mengakibatkan rangsangan terusmenerus pada saraf muskarinik dan nikotitinik. ${ }^{4}$

Salah satu populasi berisiko untuk mengalami dampak negatif jangka panjang dari penggunaan pestisida adalah petani penyemprot, hal ini berkaitan dengan keterlibatan mereka dalam kegiatan pertanian seperti mencampur pestisida, menyemprot, mencuci peralatan sampai memanen. Dampak merugikan penggunaan pestisida diantaranya adalah kesulitan bernafas, sakit kepala, efek neurologis atau psikologis, iritasi kulit dan selaput lendir. Manifestasi dari efek tersebut tergantung pada jenis pestisida dan pada tingkat dan durasi paparan. ${ }^{5}$

Negara berkembang hanya menggunakan $25 \%$ dari pestisida yang diproduksi di seluruh dunia, tetapi masyarakat di negera berkembang tersebut mengalami kematian sebesar $99 \%$ hal ini dikarenakan penggunaan pestisida di negara berkembang yang lebih intens, tidak aman, sistem peraturan, kesehatan dan pendidikan yang lebih lemah dibandingkan dengan negara maju. ${ }^{6}$

Persentase penggunaan/penyimpanan pestisida di Indonesia oleh Rumah Tangga (RT) dalam rumah sekitar $20 \%$ hal ini menunjukkan masih ada risiko paparan pestisida tidak hanya di area persawahan, tetapi juga di dalam rumah, ${ }^{7}$ sedangkan di Provinsi Jawa Tengah, proporsi rumah tangga dalam penggunaan pestisida sebesar $17,1 \%$ sedangkan proporsi penduduk umur $\geq 10$ tahun yang berperilaku benar dalam cuci tangan setelah menggunakan pestisida tahun 2013 masing-ma- $\operatorname{sing} 49,5 \%{ }^{8}$

Kabupaten Brebes merupakan daerah pertanian bawang merah terbesar di Provinsi Jawa Tengah dengan penggunaan pestisida yang tinggi pula. Berdasarkan pemeriksaan cholinesterase yang dilakukan oleh Dinas Kesehatan Kabupaten Brebes persentase keracunan selama tahun 2014-2016 sangatlah fluktuatif yaitu 5,24\%, $0,76 \%, 7,53 \%$ dan $1,44 \%$, kenaikan tersebut tidak sepenuhnya bisa dijadikan indikator yang buruk mengingat jumlah sampel yang diperiksa, tempat dan waktu pemeriksaan selalu berubah. ${ }^{9}$

Desa Dukuhlo merupakan salah satu desa di Kecamatan Bulakamba yang mengandalkan bawang merah sebagai komoditas utamanya dengan luas tanam 84 Hektar. Hasil pemeriksaan cholinesterase di Desa Dukohlo oleh DKK Kabupaten Brebes pada tahun 2013 ditemukan keracunan ringan sebesar 5,5\%. ${ }^{10-11}$

Studi di negara-negara berkembang melaporkan rendahnya tingkat pengetahuan dan buruknya praktik petani tentang pembuangan wadah sisa pestisida, selain itu juga petani tidak menggunakan APD pada saat melakukan pekerjaan, praktik penyimpanan pestisida yang tidak aman di rumah, dan pengetahuan tentang label keselamatan pestisida yang masih rendah. ${ }^{11-12}$ Dalam penelitian Boonkawee, et al. menyebutkan bahwa petani yang selalu menggunakan pelindung diri memiliki kadar serum cholinesterase lebih baik dibandingkan dengan yang tidak menggunakan pelindung diri $(p=0,001) .{ }^{13}$ Dalam penelitian lainnya menemukan bahwa petani yang melakukan kontak terakhir $\leq 2$ minggu mempunyai risiko sebesar 5,8 kali untuk mengalami keracunan dibandingkan dengan petani yang melakukan kontak terakhir $>2$ minggu yang lalu. ${ }^{14}$

Berdasarkan penjelasan dan uraian tersebut, peneliti tertarik untuk meneliti lebih lanjut mengenai faktor pengetahuan dan perilaku yang berhubunga dengan kadar serum cholinesterase pada petani penyemprot di Desa Dukuhlo Kecamatan Bulakamba Kabupaten Brebes yang bertujuan membuktikan faktor pengetahuan, merokok ketika menyemprot dan kelengkapan APD yang digunakan berhubungan dengan kadar serum cholinesterase pada petani penyemprot. 


\section{BAHAN DAN METODE}

Jenis penelitian observasional analitik dengan metode cross sectional. Penentuan jumlah sampel dalam penelitian ini menggunakan rumus uji hipotesis untuk populasi tunggal dengan teknik sampling adalah simple random sampling. Dari hasil perhitungan tersebut diperoleh besar sampel minimum sebanyak 72 sampel, tetapi dalam pelaksanaanya terdapat 88 sampel dikarenakan tingginya antusisas petani penyemprot untuk memeriksakan diri.

Variabel dependen dalam penelitian ini yaitu kadar serum cholinesterase yang didapatkan dari hasil pemeriksaan laboratorium oleh Laboratorium Cito Tegal. Variabel independen yang diteliti adalah pengetahuan tentang pestisida, merokok ketika menyemprot dan kelengkapan APD yang digunakan ketika menyemprot. Pengumpulan data primer dilakukan dengan wawancara menggunakan kuesioner yang sebelumnya sampel telah diberikan informed concent. Hasil penelitian dianalisis secara bivariat menggunakan yaitu chi square $\left(\mathrm{x}^{2}\right)$ dengan tingkat kemaknaan $\mathrm{p}<0,05$, confidence interval (CI) $95 \%$ dan analisis multivariat dengan multipel regresi logistik.

\section{HASIL}

Penelitian dilakukan di Desa Dukuhlo Kecamatan Bulakamba Kabupaten Brebes Provinsi Jawa Tengah pada 88 petani penyemprot. Sebagian besar petani penyemprot berusia $\geq 45$ tahun $(72,2 \%)$, berpendidikan $\mathrm{SD} /$ Sederajat $(51,1 \%)$, waktu terakhir menyemprot $0-2$ hari yang lalu $(38,6 \%)$, jenis tanaman yang disempeor tiga bulan terakhir adalah padi $(72,7)$ dan jenis pestisida yang banyak digunakan adalah merk "Dusban" $(37,5 \%)$. Berdasarkan tingkat pengetahuan tentang pestisida, diketahui bahwa sebagian besar petani penyemprot mempunyai tingkat pengetahuan tentang pestisida yang baik (58\%). Dilihat dari perilaku subjek ketika menyemprot, diketahui bahwa sebagian besar responden kelengkapan APD ketika menyemprot adalah baik $(72,7 \%)$ dan tidak merokok ketika menyemprot $(81,8 \%)$. Hasil pemeriksaan serum cholinesterase diperoleh petani penyemprot yang memiliki kadar serum cholinesterase yang rendah $(<5,320 \mathrm{U} / \mathrm{L})$ sebesar 13,6\% (Tabel 1).

Hasil analisis bivariat dengan uji chi-
Tabel 1. Hasil Analisis Univariat Karakteristik Responden dan Variabel Penelitian

\begin{tabular}{lcc}
\hline \multicolumn{1}{c}{ Variabel } & $\mathbf{n}$ & $\mathbf{\%}$ \\
\hline Usia & & \\
Usia $>45$ tahun & 64 & 72,2 \\
Usia $<45$ tahun & 24 & 27,3 \\
Tingkat Pendidikan & & \\
Tidak pernah sekolah & 18 & 20,5 \\
Tidak Tamat SD & 8 & 9,1 \\
Tamat SD/Sederajat & 45 & 51,1 \\
Tamat SLTP/Sederajat & 11 & 12,5 \\
Tamat SLTA/Sederajat & 5 & 5,7 \\
Tamat Diploma & 1 & 1,1 \\
Waktu Terakhir menyemprot & & \\
0-2 hari yang lalu & 34 & 38,6 \\
3-7 hari yang lalu & 26 & 29,6 \\
14-60 hari yang lalu & 28 & 31,8 \\
Jenis merk pestisida yang digunakan & & \\
Dusban (Klorpirifos 200 g/l) & 33 & 37,5 \\
Buldog (Betasiflutrin 25 g/l) & 27 & 30,6 \\
Emma (Emamektin Benzoat 22g/l) & 18 & 20,4 \\
Decis (Deltametrin 25 g/l) & 15 & 17,0 \\
Starban (Klorpirifos 530 g/l) & 13 & 14,7 \\
Bameks (Alfa Sipermetrin) & 11 & 12,5 \\
Arjuna (Klorfenapir 200 g/l) & 9 & 10,2 \\
Ditan (Mankozeb) & 9 & 10,2 \\
Pengetahuan tentang pestisida & & \\
Rendah & 37 & 42 \\
Baik & 51 & 58 \\
Merokok ketika menyemprot & & \\
Ya & 16 & 14,8 \\
Tidak & 72 & 81,8 \\
Kelengkapan APD & & \\
Buruk & 13 & 14,8 \\
Baik & 75 & 85,2 \\
Kadar serum cholinesterase & & \\
Rendah (<5,320 U/L) & 12 & 13,6 \\
Normal ( $\geq 5,320$ U/L) & 76 & 86,4 \\
\hline
\end{tabular}

Sumber: Data Primer, 2017

square diketahui bahwa faktor yang berhubungan dengan kadar serum cholinesterase pada petani penyemprot adalah merokok ketika menyemprot $(\mathrm{p}=0,008$; RP 4,5 ; $95 \%$ CI $1,6-12,1)$ dan pengetahuan tentang pestisida ( $\mathrm{p}=0,005 ; \mathrm{RP} 6,9 ; 95 \%$ CI 1,6-29,6) (Tabel 2). Variabel dengan nilai $\mathrm{p}<0,25$ dimasukkan dalam analisis multivariat meliputi merokok ketika menyemprot dan pengetahuan tentang pestisida. Hasil analisis multivariat regresi logistik diketahui bahwa faktor yang yang berhubungan dengan kadar serum cholinesterase pada petani penyemprot adalah merokok 
Tabel 2. Hasil Analisis Bivariat Faktor yang Berhubungan dengan Kadar Serum Cholinesterase pada Petani Penyemprot

\begin{tabular}{|c|c|c|c|c|c|c|}
\hline \multirow{3}{*}{ Variabel } & \multicolumn{4}{|c|}{ Kadar Serum Cholinesterase } & \multirow{3}{*}{$\mathbf{p}$} & \multirow{3}{*}{$\begin{array}{c}\text { RP } \\
(95 \% \mathrm{CI})\end{array}$} \\
\hline & \multicolumn{2}{|c|}{ Rendah } & \multicolumn{2}{|c|}{ Normal } & & \\
\hline & n & $\%$ & n & $\%$ & & \\
\hline \multicolumn{7}{|l|}{ Pengetahuan } \\
\hline Kurang ( $\mathrm{n}=37)$ & 10 & 27,0 & 27 & 73,0 & \multirow[t]{2}{*}{0,005} & 6,9 \\
\hline Baik $(\mathrm{n}=51)$ & 2 & 3,9 & 49 & 96,1 & & $(1,6-29,6)$ \\
\hline \multicolumn{7}{|c|}{ Kebiasaan merokok ketika menyemprot } \\
\hline$Y a(n=16)$ & 6 & 37,5 & 10 & 62,5 & \multirow{2}{*}{0,008} & 4,5 \\
\hline Tidal $(\mathrm{n}=72)$ & 6 & 8,3 & 66 & 91,7 & & $(1,6-12,1)$ \\
\hline \multicolumn{7}{|l|}{ Kelengkapan APD } \\
\hline Buruk $(n=76)$ & 12 & 92,3 & 64 & 85,3 & \multirow[t]{2}{*}{0,811} & 0,5 \\
\hline Baik $(n=12)$ & 1 & 7,7 & 11 & 14,7 & & $(0,07-3,7)$ \\
\hline
\end{tabular}

Sumber: Data Primer, 2017

Tabel 3. Hasil Uji Multiple Logistic Regresion Faktor yang Paling Berhubungan Kadar Serum Cholinesterase pada Petani Penyemprot

\begin{tabular}{lcccc}
\hline \multicolumn{1}{c}{ Variabel } & B & Nilai p & Exp (B) / OR & $\mathbf{9 5 ~ \% ~ C I ~}$ \\
\hline Pengetahuan tentang pestisida & 2,515 & 0,005 & 12,369 & $2,138-71,556$ \\
Merokok ketika menyemprot & 2,266 & 0,005 & 3,863 & $2,013-46,161$ \\
Constant & $-4,057$ & 0,000 & 0,017 & \\
\hline
\end{tabular}

Sumber: Data Primer, 2017

Keterangan : $p<0,05$

ketika menyemprot $(\mathrm{p}=0,005 ; \mathrm{OR}=12,369 ; 95 \%$ $\mathrm{CI}=2,1-71,5)$ dan pengetahuan tentang pestisida $(\mathrm{p}=0,005 ; \mathrm{OR}=9,641 ; 95 \% \mathrm{CI}=2,0-46,1)($ Tabel 3$)$.

\section{PEMBAHASAN}

Proporsi petani penyemprot dengan kadar serum cholinesterase rendah lebih besar pada kelompok petani yang merokok ketika menyemprot (37,5\%) dibandingkan tidak merokok ketika menyemprot $(8,3 \%)$. Hasil analisis multivariat menyatakan bahwa petani penyemprot yang merokok ketika menyemprot mempunyai risiko 12,369 lebih besar mempunyai kadar serum cholinesterase yang rendah dibandingkan petani penyemprot yang tidak merokok ketika menyemprot $(\mathrm{p}=0,005 ; \mathrm{OR}=12,369 ; 95 \% \mathrm{CI}=2,1$ 71,5). Petani yang merokok ketika sedang menyemprot artinya tidak menggunakan alat pelindung diri berupa masker, pada saat petani menghisap rokok maka secara otomatis pestisida yang berada di udara juga masuk melalui hidung. Pada asap rokok, terkandung berbagai senyawa, diantaranya tar dan nikotin yang ternyata mempunyai pengaruh terhadap cholinesterase. ${ }^{15}$

Penelitian ini sejalan dengan penelitian Ruhendi yang menunjukkan hubungan bermakna dengan aktivitas cholinesterase darah adalah merokok saat menyemprot $(\mathrm{p}=0,0001, \mathrm{OR}=6,582$, 95\% CI $=2,881-15,037) .{ }^{16}$ Dalam penelitian lainnya juga menunjukkan bahwa merokok yang lebih sedikit merupakan faktor protektif dalam risiko keterpaparan pestisida ke dalam tubuh (PD -0.20; CI-0.34, -0.07). ${ }^{17}$ Hasil analisis multivariat dalam penelitian Kachaiyaphum, et al. menunjukkan bahwa terdapat hubungan antara kebiasaan penggunaan pestisida yang sedang atau buruk dengan kadar SchE yang abnormal dibandingkan dengan kebiasaan yang baik, kebiasaan dalam hal ini adalah merokok ketika menyiapkan dan mengaplikasikan pestisida. ${ }^{18}$

Berdasarkan hasil penelitian di lapangan diperoleh informasi bahwa alasan petani penyemprot yang merokok ketika menyemprot yaitu mereka tidak merasakan efek kesehatan yang negatif, mereka merasa sudah kebal dan kuat terhadap paparan asap rokok walaupun pada saat menyemprot. 
Setelah menyemprot mereka beristirahat untuk makan dan minum kemudian merokok kembali.

Proporsi petani penyemprot dengan kadar serum cholinesterase rendah lebih besar pada kelompok pengetahuan tentang pestisida yang kurang (27\%) dibandingkan pengetahuan baik $(3,9 \%)$. Petani penyemprot yang pengetahuan tentang pestisida yang rendah mempunyai risiko 9,641 kali lebih besar mempunyai kadar serum cholinesterase yang rendah dibandingkan petani penyemprot yang memiliki pengetahuan tentang pestisida yang baik $(\mathrm{p}=0,005 ; \mathrm{OR}=9,641 ; 95 \%$ $\mathrm{CI}=2,0-46,1)$. Hasil penelitian ini sejalan dengan penelitian yang dilakukan oleh Budiawan yang menghasilkan hubungan yang signfikan antara tingkat pengetahuan dengan cholinesterase petani bawang merah di Ngurensiti Pati $(\mathrm{p}=0,002) .{ }^{19}$

Pengetahuan adalah hasil dari tahu dan terjadi setelah melakukan penginderaan terhadap objek tertentu. Sebagian besar pengetahuan manusia diperoleh melalui mata dan teliga. Pengetahuan merupakan hal yang sangat penting dalam membentuk tindakan seseorang. Teori Cognitive Consistency bahwa terdapat hubungan konsisten dalam diri seseorang yaitu pengetahuan, sikap dan perilaku. Perilaku dapat diubah dengan cara merubah pengetahuan dan sikap. Proses pendidikan akan berpengaruh pada perubahan pengetahuan dan merubah sikap seseorang yang akan menghasilkan perubahan pada perilaku. Pengetahuan dapat diperoleh seseorang melalui berbagai macam alat bantu seperti media cetak, media elektronik (televisi, radio, video, slide) dan media papan yang berisi pesan kesehatan. ${ }^{20}$ Berdasarkan hasil penelitian di lapangan diperoleh informasi bahwa belum ada penyuluhan tentang bahaya pestisida bagi petani penyemprot.

Peningkatan pengetahuan bagi petani penyemprot tentang informasi umum tentang pestisida, faktor risiko keracunan pestisida sampai dengan pencegahan keracunan perlu dilakukan untuk menurunkan kejadian rendahnya kadar serum cholinesterase petani penyemprot. Pemeriksaan cholinesterase secara rutin oleh Dinas Kesehatan Kabupaten Brebes juga perlu dilakukan untuk memonitoring kadar cholinesterase khususnya petani penyemprot yang intensitas penggunaan pestisidanya sangat tinggi.

\section{KESIMPULAN DAN SARAN}

Merokok ketika menyemprot dan pengetahuan tentang pestisida yang rendah merupakan faktor yang berhubungan dengan kadar serum cholinesterase pada petani penyemprot di Desa Dukuhlo Kecamatan Bulakamba Kabupaten Brebes. Petani penyemprot yang merokok ketika menyemprot mempunyai risiko 12,369 lebih besar mempunyai kadar serum cholinesterase yang rendah dibandingkan petani penyemprot yang tidak merokok ketika menyemprot dan pengetahuan tentang pestisida yang rendah mempunyai risiko 9,641 kali lebih besar mempunyai kadar serum cholinesterase yang rendah dibandingkan petani penyemprot yang memiliki pengetahuan tentang pestisida yang baik. Bagi peneliti lain disarankan dengan mencari responden yag lebih banyak dan diukur kadar serum cholinesterasenya sehingga dapat menemukan petani penyemprot yang memiliki kadar serum cholinesterase yang tidak normal untuk dijadikan kasus sehingga bisa melakukan penelitian dengan desain case control. Bagi institusi kesehatan diharapkan untuk lebih banyak menjaring petani penyemprot untuk dilakukan tes cholinesterase untuk memantau paparan pestisida yang bisa timbul khususnya di daerah pertanian yang intensitas penggunaan pestisidanya sangat tinggi serta meningkatkan promosi kesehatan tentang informasi umum tentang pestisida, faktor risiko keracunan pestisida sampai dengan pencegahan keracunan. Bagi petani penyemprot disarankan untuk menghindari aktivitas merokok ketika sedang menyemprot serta mencari tahu tentang pestisida baik itu cara masuk pestisida ke dalam tubuh, gejala keracunan dan cara perlindungan diri agar tidak kontak langsung dengan pestisida.

\section{UCAPAN TERIMA KASIH}

Penelitian ini terlaksana atas bimbingan dari Bapak Dr. Dr. Suhartono, M.Kes, Dr. Bagoes Widjanarko, MPH, Dr. Mateus Sakundarno Adi, M.Sc, Ph.D, Suratman. SKM, M.Kes, Ph.D serta Laboratorium Cito Tegal.

\section{DAFTAR PUSTAKA}

1. FAO. The International Code of Conduct on Pesticide Management. Rome: FAO; 2014. p. 6.

2. Sanborn M, Kerr KJ, Sanin LH, Cole DC, 
Bassil KL, Vakil C. Non-cancer Health Effects of Pesticides Systematic Review and Implications for Family Doctors. Can Fam Physician. 2007. p. 53.

3. Ogg, C.L., et al. Managing the risk of pesticide poisoning and understanding the sign and symproms. Extenstion. University of Nebraska-Lincoln. 2012

4. Wudiyanto R. Petunjuk Penggunaan Pestisida. Jakarta: Swadaya; 2008.

5. Bretveld RW, Thomas CMG, Scheepers PTJ, Zielhuis GA, Roeleveld N. Pesticide exposure: The Hormonal Function Of The Female Reproductive System Disrupted? reproductive system disrupted? Artic Rev. 2017. p. 4

6. World Health Organization. Pesticides -Children's Health and the Environment. In 2008.

7. Kemenkes RI. Riset Kesehatan Dasar. Jakarta: Kemenkes RI; 2013.

8. Kementerian Kesehatan RI. Riskesdas dalam Angka Provinsi Jawa Tengah. Lembaga Penerbitan Badan Penelitian dan Pengembangan Kesehatan; 2013.

9. DKK Kabupaten Brebes. Profil Kesehatan Kabupaten Brebes 2014. Kabupaten Brebes: Dinas Kesehatan Kabupaten Brebes; 2014

10. BPS. Statistik Pertanian Hortikultura Jawa Tengah 2012-2014. Jawa Tengah; 2016.

11. Ibitayo OO. Egyptian Farmers 'Attitudes and Behaviors Regarding Agricultural Pesticides': Implications for Pesticide Risk Communication. Risk Anal. 2006;26(4).

12. Ajayi OC, Akinnifesi FK, Programme SA, Box PO. Farmers 'understanding of pesticide safety labels and field spraying practices: a case study of cotton farmers in northern Côte d 'Ivoire. Sci Res Essays. 2007;2(June):204-10.

13. Boonyakawee, P., Taneepanichskul, S., Chapman, R.S. Knowledge, Attitude and Practice in
Insecticide Use, Serum Cholinesterase Levels and Symptom Prevalence among Shogun Orange Farmers in Khao-Phanom District, Krabi Province Thailand. J Health Res. 2013; 27(3): 196-191.

14. Suryamah. Analisis Pemajanan Pestisida dengan Tingkat Keracunan Pestisida pada Petani Perkebunan di Kabupaten Bandung Tahun 2006. [Tesis]. Depok: UI; 2007

15. Rustia, H.N, Wispriyono B, Susanna D, Luthfiah FN, Sosial BK, Pengkajian P, et al. Lama Pajanan Organofosfat Terhadap Penurunan Aktivitas Enzim Kolinerase Dalam Darah Petani Sayuran. Makara Kesehat. 2010;14(2):95-101.

16. Ruhendi, D. Faktor Determinan Aktivitas Kholinesterase Darah Petani Holtikultura di Kabupaten Majalengka. J Kesehat Masy Nas. 2007;45461:215-9.

17. Issa, Y., Sham'a, F.A., Nijem, K., Bjertness, E., Kristensen, P. Pesticide use and opportuniies of exposure among farmers and their families: cross-sectional studies 1998-2006 from Hebron governorate, occupied Palestinian territory. Environmental Health. 2010. 9 (63).

18. Kachaiyaphum, ujirat, D., Siri. D., Suwannapong, N. Serum Cholinesterase Levels of Thai Chili-Farma Workers Exposed to Chemical Pesticides: Prevalence Estimates and Associated Factors. 2010. 52.

19. Budiawan AR. Faktor Risiko yang Berhubungan dengan Cholinesterase Pada Petani Bwang Merah di Ngurensiti Pati. Unnes J Public Heal. 2014;3(1):1-11.

20. Long, R. Introductory Sociology, Sosial Class (Stratification). http://dmc122011.delmar.edu/ socsci/rlong/intro/class.htm. 2013. 